\title{
COVID-19 vaccine and immune response
}

\author{
Sevilay Hintistan ${ }^{1}\left(\mathbb{D}\right.$, Hatice Demirağ ${ }^{2}{ }^{*}$ \\ ${ }^{1}$ Faculty of Health Sciences Nursing Department, Internal Medicine Nursing, Karadeniz Technical University, Trabzon \\ 61000, Turkey \\ ${ }^{2}$ Department of Medical Services and Techniques, First and Emergency Aid Program, Gümüşhane University, Gümüşhane \\ 29600, Turkey
}

*Correspondence: Hatice Demiră̆, Department of Medical Services and Techniques, First and Emergency Aid Program, Gümüşhane University, Gümüşhane 29600, Turkey. hatice_etbas@hotmail.com

Academic Editor: Narinder K. Mehra, Indian Council of Medical Research, India

Received: July 5, 2021 Accepted: November 3, 2021 Published: December 31, 2021

Cite this article: Hintistan S, Demirağ H. COVID-19 vaccine and immune response. Explor Immunol. 2021;1:341-55. https:// doi.org/10.37349/ei.2021.00023

\begin{abstract}
Severe acute respiratory syndrome coronavirus 2 (SARS-CoV-2; $\beta \mathrm{CoV}$ ), the causative agent of coronavirus disease 2019 (COVID-19), causes severe lower respiratory tract infections and acute respiratory failure syndrome (ARDS). Deaths due to the ongoing COVID-19 pandemic for more than a year are still seen worldwide. Therefore, vaccine trials have gained importance. The discovery of the genome and protein structure of SARS-CoV-2 in a short time allowed the development of nucleic acid-based vaccines (mRNA and DNA vaccines), vector vaccines, inactivated virus vaccines, protein-based vaccines, virus-like particle vaccines, and live attenuated virus vaccines. Many companies, universities, and institutes around the world continue to develop effective vaccines against SARS-CoV-2. In this review, the structural features, classification, genome, and intracellular entry of SARS-CoV-2 coronaviruses, stimulation of the immune system and immunity, COVID-19 vaccine types, and the latest status of clinical trials of these vaccines have been reviewed.
\end{abstract}

\section{Keywords}

COVID-19, vaccine, immune response

\section{Introduction}

Coronaviruses ( $\mathrm{CoV}$ ) are common zoonotic pathogens that cause upper respiratory tract infections [1].

Derived from the combination of CO (Corona), VI (Virus), D (Disordine/Disease), and 19 (the year 2019), evere acute respiratory syndrome coronavirus 2 (SARS-CoV-2) is a zoonotic RNA virus that leads to the coronavirus disease 2019 (COVID-19) in humans or animals. COVID-19 is an infectious disease caused by SARS-CoV-2, known as "2019 novel coronavirus" or "2019-nCoV" [2, 3].

Although coronaviruses were discovered in the 1960s, the COVID-19 outbreak first reported as cases of pneumonia of unknown etiology in people working in the seafood and livestock market in Wuhan, China, on 31 December 2019. It was only realized on January 7, 2020, that the disease agent was a new type of 
coronavirus $[4,5]$. Then, on January 12,2020 , the genome sequence of the virus was determined by the "Global Initiative on Sharing All Influenza Data (GISAID)" and was defined as "2019 new coronavirus (2019-nCoV)" by the World Health Organization (WHO) [6]. After China, the first cases were seen in Thailand on January 13, 2020, and in Japan on January 16, 2020, and after being detected in Italy on January 30, 2020, it was declared as an "international health emergency" by the WHO Emergency Committee on this date. Then, the epidemic spread to many countries, and on February 11,2020, the disease caused by the virus was updated as COVID-19, and the virus causing it was updated as "severe acute respiratory syndrome coronavirus-2" (SARS-CoV-2) [4, 5]. The disease was declared a "pandemic" on March 11, 2020 (Figure 1) [5] and caused $3,744,408$ deaths in the world as of June 9, 2021. Deaths due to COVID-19 continue all over the world [7]. To prevent or reduce deaths due to COVID-19 or its complications, it is necessary to inhibit the excessive immune response of the human body against SARS-CoV-2, which seems possible with immunotherapy [8].

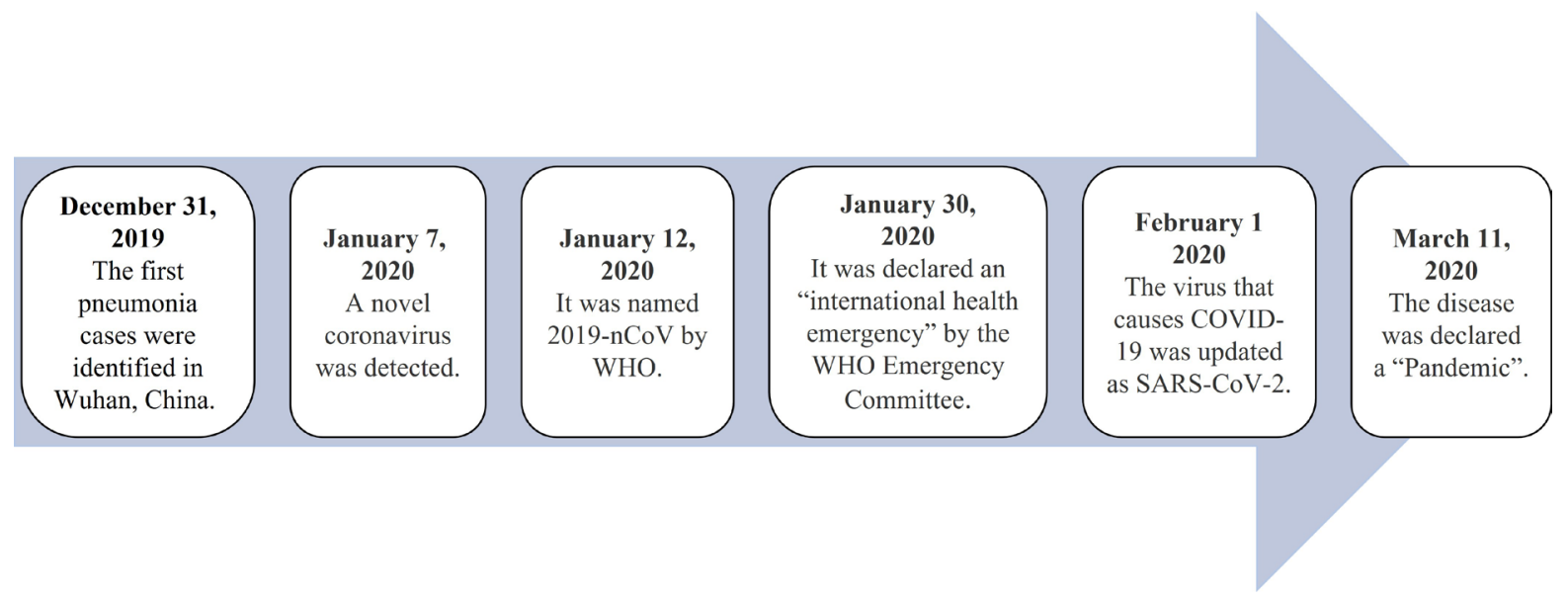

Figure 1. COVID-19 pandemic period

Immunotherapy is a method of creating an immune response through artificial stimulation of the immune system for the prophylaxis and treatment of various diseases (infectious diseases, cancers, etc.) [9]. The main function of COVID-19 vaccines, which aim to create an immune response, is to produce S protein neutralizing antibodies in administered individuals [10]. The National Center for Biotechnology Information (NCBI) has approximately sequenced 5500 SARS-CoV-2 genomes isolated in various countries [11]. The elucidation of the sequencing of the SARS-CoV-2 genome through genetic technologies has accelerated vaccine studies. This review aims to present the structural features, classification, genome, and intracellular entry of SARS-CoV-2 coronaviruses, stimulation of the immune system and immunity, COVID-19 vaccine types, and the latest status of clinical trials of these vaccines.

\section{Structural features, classification, and genome of SARS-COV-2 coronaviruses}

Coronaviruses are the largest enveloped, single-stranded RNA viruses. There are 27 coded proteins in their genomes [12-14]. The virus, which is about $150-160 \mathrm{~nm}$ in size, is morphologically polymorphic or round, and has spiny protrusions called "spikes" on the surface of the virus, which make it appear like a crown. For this reason, the virus with the appearance of a crown is called "corona", which means crown [15-17].

The Coronaviridae family is divided into two subfamilies: Torovirinae and Coronavirinae. The Coronavirinae family includes 4 genera; alphacoronavirus $(\alpha \mathrm{CoV})$ and Betacoronavirus $(\beta \mathrm{CoV})$ infecting humans and other mammals; $\alpha \mathrm{CoV}$ and gammacoronavirus $(\gamma \mathrm{CoV})$ infecting whales and birds; and deltacoronavirus $(\delta \mathrm{CoV})$ infecting pigs and birds $[12,13,18,19]$. In the twentieth century, 7 coronaviruses that are potentially dangerous to humans were identified. While HCoV 229E ( $\alpha \mathrm{CoV}$ ), NL63 ( $\alpha \mathrm{CoV})$, HCoV-OC43 $(\beta \mathrm{CoV})$ and HCoV-HKU1 $(\beta \mathrm{CoV})$ cause upper respiratory tract infections, SARS-CoV $(\beta \mathrm{CoV})$, the causative agent of MERS-CoV $(\beta \mathrm{CoV})$, and SARS-CoV-2 $(\beta \mathrm{CoV})$, and COVID-19, cause severe lower respiratory tract infections and acute respiratory failure syndrome (ARDS) $[12,18,19]$. Besides, regarding the first case of 
COVID-19, it is estimated that SARS-CoV-2 is not directly transmitted to humans, nor is it directly transmitted from bats to humans, and an animal called Pangolin is an intermediate host.

Coronaviruses encode the following five structural proteins in their genomes. Spike (S), membrane (M), envelope (E) glycoproteins, hemagglutinin esterase (HE), and nucleocapsid (N) protein (Figure 2) [20, 21]. While envelope glycoproteins and $\mathrm{N}$ protein are found in all virions, HE proteins are found only in $\beta$ CoVs [22]. $S$ glycoproteins located outside the virion give the virion its typical shape, $M$ proteins are involved in the regeneration of virions in the cell, and E proteins play a significant role in the assembly and morphogenesis of virions [23-25]. In addition, $\mathrm{N}$ proteins in phosphoprotein structure with the ability to bind to the helix have a significant impact on the virion structure, replication, and transcription of coronaviruses [26].

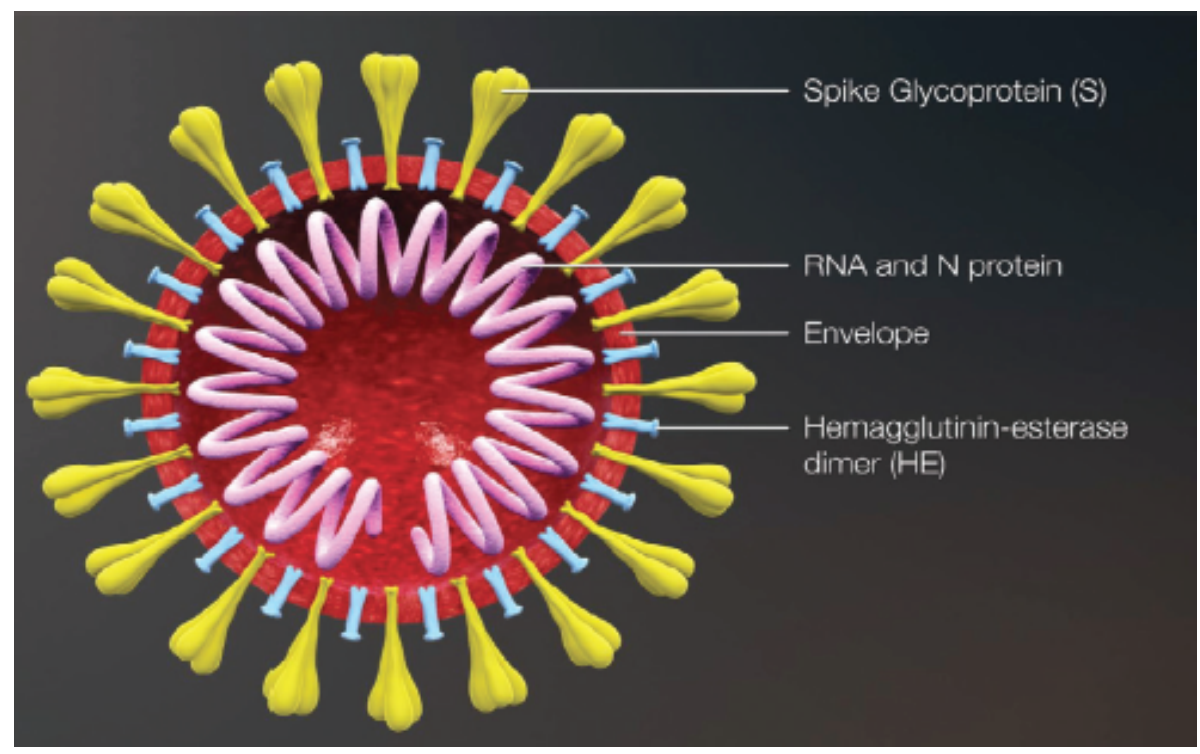

Figure 2. Coronavirus virion structure [20]

Note. Reprinted from "Vaccination studies against COVID-19 agent: current status" by Hindistan S, Kazak A. Bezmialem Science. 2020;8:145-52 (https://cms.galenos.com.tr/Uploads/Article_42785/BezmialemScience-8-145-En.pdf). (C) 2021, Bezmiâlem Vakıf University.

The genome size of SARS-CoV-2 is between $29.8 \mathrm{~kb}-29.9 \mathrm{~kb}$ (approximately $30 \mathrm{~kb}$ ). There are two non-translated regions at the 5' (cap structure) and 3' (polyA tail) ends of the genome. Between these two regions, there are 8-10 open reading frames (ORFs). ORF1a and ORF1b, which make up two-thirds of the 5' end of the virus genome, encode the polyprotein1a (pp1a) and pp1ab proteins. One-third of the 3' end of the genome consists of genes encoding structural proteins, including $\mathrm{S}, \mathrm{E}, \mathrm{M}$, and N proteins. The SARS-CoV-2 genome has 6 accessory proteins encoded by the ORF3a, ORF6, ORF7a, ORF7b, and ORF8 genes [27].

\section{Intracellular entry of SARS-CoV-2}

SARS-CoV-2 can enter the cell through two different mechanisms. The first one is direct membrane fusion via angiotensin converting enzyme 2 (ACE2) receptors. The S protein of SARS-CoV binds to ACE2 receptors and combines with the plasma membrane. With the proteolysis of the $\mathrm{S}$ protein binding to the ACE receptor, the most important stage of the virus's life cycle has been achieved [28]. ACE2 receptors on endothelial cells of organs such as lungs, intestines, heart, and kidneys cause viral inclusions in endothelial cells after encountering the virus. During virus entry, the affected renin-angiotensin system (RAS) as a result of the ACE2 receptor being taken into the cell and degraded causes angiotensin- 2 increase. As a result of endothelial cell infection, endotheliitis, apoptosis, disruption of RAS balance, ischemia, edema, and hypercoagulability may develop $[29,30]$. It is also estimated that the stroke and hypertensive crisis observed in COVID-19 patients may be related to this mechanism [31].

Another way of entry of SARS-CoV-2 into the cell is "antibody-dependent enhancement" (ADE) defined in some virus infections [such as dengue virus, Ebola virus, human immunodeficiency virus (HIV)), and 
SARS-CoV. In SARS-CoV infections, ADE is thought to be associated with Fc receptors (FcRs) expressed on different immune cells such as monocytes, macrophages, and B cells. In the presence of anti-S antibodies, the virus enters the cells with the Fc-gamma-2 (CD32) receptor on its surface in the form of an antibody-virus complex and shows a cytopathic effect. It is also predicted that SARS-CoV entering monocyte-macrophage cells with ADE may have effects on cytokine/chemokine release and cell apoptosis. Although the virus can enter the cell in this way, it has not yet been proven that it can multiply inside the cell and then be released from the cell again [32,33].

\section{Immunity and stimulation of immunity}

As the virus enters the cell, antigen-presenting cells (APC) present viral antigens first. Virus-specific cytotoxic $\mathrm{T}$ lymphocytes recognize antigenic peptides presented by the major histocompatibility complex (MHC) or human leukocyte antigen (HLA) in humans. MHC I and MHC II are involved in antigen presentation. As a result of antigen presentation, the virus-specific humoral and cellular immune response is stimulated, and immunoglobulin M (IgM) and IgG type antibodies are formed against SARS-CoV-2 [34, 35]. Antibodies begin to be detected sometime after the infection develops (IgM antibodies on 7-21 days, IgG on 14 days). It has been shown that IgG-type antibodies form and persist for a long time against $\mathrm{S}$ and $\mathrm{N}$ antigens [35]. SARS-CoV-2 induces the formation of double-membrane vesicles that lack the pattern-recognition receptor (PRR) and proliferate within these vesicles to escape the immune system and maintain intracellular life. Thus, the host is prevented from noticing the RNA of the virus. As a result, antigen presentation is controlled by the virus [36].

\section{Sekretory (Humoral) immunity}

The humoral immune response to SARS-CoV-2 is achieved by antibodies targeting the surface S-glycoprotein [especially the receptor-binding domain (RBD) region] and the nucleocapsid protein. IgM, IgA, and IgG antibodies develop in the blood serum levels of individuals who have been vaccinated or have experienced COVID-19, and viral clearance and neutralization of anti-S glycoprotein and anti-RBD in these antibodies are carried out [37]. High levels of IgM, IgA, and IgG antibodies detected in the blood serum of people who have had the disease protect them from the disease. IgA antibody peak at the blood serum level on days 20-22 of the disease, IgM antibody on days 10-12, and IgG antibody in the 3rd week of the disease. Immediately afterward, on the 18th day of the disease, IgM antibodies decrease and disappear, and the IgG antibody begins to decrease after the 8th week [38]. The level of antibodies in the blood serum varies according to the severity of the disease. The level of antibodies formed in people with the mild disease is lower and disappear in a shorter time [39]. A reviewed literature reports disappearance of IgG within 2-3 months after infection in $40 \%$ of people with asymptomatic COVID-19 and 13\% of people with symptomatic [40]. Contrary to this study, which showed that the antibodies formed decreased and disappeared in a short time, in a study conducted in Iceland, it was found that IgG antibodies continued unabated for 4 months [41]. The short-term reduction of antibodies indicates that people who have had COVID-19 may become ill again [42], suggesting that the effect of COVID-19 vaccines may not be long-lasting [42, 43].

\section{Cellular immunity}

In people infected with SARS-CoV-2 CD38 ${ }^{+}, \mathrm{HLA}_{-} \mathrm{DR}^{+} \mathrm{T}$ cells $\left(\mathrm{CD} 4^{+}\right.$and $\mathrm{CD}^{+}$) increase 7-10 days after symptoms begin and return to normal around day 20 [44,45]. S-protein-specific activated CD38 ${ }^{+} \mathrm{T}$ cells were found in $83 \%$ of COVID-19 cases [44]. However, some people who have not been exposed to SARS-CoV-2 have $\mathrm{CD}^{+}$and $\mathrm{CD}^{+} \mathrm{T}$ lymphocytes that respond to a certain amount of S-protein. It is estimated that this may be due to cross-resistance with seasonal coronavirus infections [46]. A relevant study reported that virus-specific T lymphocytes showed acute cytotoxic effect during infection in 203 patients with COVID-19, and memory lymphocytes were dominant and polyclonal in the convalescent period. In the same study, a cellular response was found in individuals without antibodies [47]. Likewise, in another study, memory T-cell response was reported to develop in some patients in whom specific antibodies could not be detected [48]. These findings demonstrate that the cellular response and the ability of vaccines to induce cellular responses 
are important in the prevention of COVID-19. An ideal vaccine should both generate neutralizing antibodies and activate Thelper 1 (Th1)-responsive cellular immune elements [49].

\section{COVID-19 vaccines}

Vaccine development trials against SARS-CoV-2 started in the first month of the epidemic. As of 11 June 2021, there were 287 COVID-19 ongoing vaccine trials worldwide, 102 of which are clinical phase studies and 185 are preclinical studies (Table 1) [50].

Table 1. Main vaccine types and phase 3-4 candidates as of June 2021 [50]

\begin{tabular}{|c|c|c|c|c|c|c|c|}
\hline $\begin{array}{l}\text { Vaccine platform } \\
\text { description }\end{array}$ & $\begin{array}{l}\text { Number of } \\
\text { candidate } \\
\text { vaccines }\end{array}$ & $\%$ & $\begin{array}{l}\text { Number } \\
\text { of doses }\end{array}$ & Schedule & $\begin{array}{l}\text { Route of } \\
\text { administration }\end{array}$ & $\begin{array}{l}\text { Developers (Candidate } \\
\text { vaccine type) }\end{array}$ & Phase \\
\hline \multirow[t]{4}{*}{ mRNA vaccines } & 16 & 16 & 2 & Day $0+28$ & i.m & Moderna (mRNA 1273) & Phase $4^{*}$ \\
\hline & & & 2 & Day $0+2$ & i.m. & Pfizer/BioNTech (BNT162b2) & Phase $4^{*}$ \\
\hline & & & 2 & Day $0+28$ & i.m. & CureVac AG (CVnCoV) & Phase 3 \\
\hline & & & 2 & $\begin{array}{l}\text { Day } 0+14 \\
\text { or Day } 0 \\
+28\end{array}$ & i.m. & $\begin{array}{l}\text { Academy of MilitaryScience } \\
\text { (AMS)/(ARCoV) }\end{array}$ & Phase 3 \\
\hline \multirow[t]{5}{*}{ Vectorvaccines } & 18 & 18 & $1-2$ & Day $0+28$ & i.m. & $\begin{array}{l}\text { Oxford/Astra Zeneca } \\
(\text { ChAdOx1) }\end{array}$ & Phase $4^{*}$ \\
\hline & & & 1 & Day 0 & i.m. & $\begin{array}{l}\text { CansinoBiologicallnc. (Ad5- } \\
\text { nCoV) }\end{array}$ & Phase 4 \\
\hline & & & 2 & Day $0+21$ & i.m. & $\begin{array}{l}\text { Sputnik V (Gam-COVID-Vac) } \\
\text { (rAd26-S+rAd5-S) }\end{array}$ & Phase 3 \\
\hline & & & $1-2$ & $\begin{array}{l}\text { Day } 0 \text { or } \\
\text { Day } 0+56\end{array}$ & i.m. & $\begin{array}{l}\text { Johnson\&Johnson/ Janssen } \\
\text { Pharmaceutical (Ad26. } \\
\text { COV2.S) }\end{array}$ & Phase $3^{*}$ \\
\hline & & & 1 & Day 0 & i.m. & $\begin{array}{l}\text { ReiThera + Leukocare + } \\
\text { Univercells (GRAd-COV2) }\end{array}$ & Phase $2 / 3$ \\
\hline Inactivated virus & 16 & 16 & 2 & Day $0+14$ & i.m. & CoronaVac (Sinovac) & Phase $4^{*}$ \\
\hline \multirow[t]{8}{*}{ vaccines } & & & 2 & Day $0+21$ & i.m. & Sinopharm/WIBP-CorV & Phase $3^{*}$ \\
\hline & & & 2 & Day $0+28$ & i.m. & $\begin{array}{l}\text { Institute of Medical Biology } \\
\text { (verocells) }\end{array}$ & Phase 3 \\
\hline & & & 2 & Day $0+21$ & i.m. & $\begin{array}{l}\text { Research Institute for } \\
\text { Biological Safety Problems } \\
\text { (QazCovid-in) }\end{array}$ & Phase 3 \\
\hline & & & 2 & Day $0+14$ & i.m. & Bharat Biotech(BBV152) & Phase 3 \\
\hline & & & 2 & Day $0+28$ & i.m. & $\begin{array}{l}\text { Shenzhen Kangtai Biological } \\
\text { Products (Verocell) }\end{array}$ & Phase 3 \\
\hline & & & 2 & Day $0+21$ & i.m. & $\begin{array}{l}\text { Valneva, National Institute } \\
\text { for Health Research, United } \\
\text { Kingdom (VLA2001) }\end{array}$ & Phase 3 \\
\hline & & & 2 & Day $0+21$ & i.m. & $\begin{array}{l}\text { Erciyes University and the } \\
\text { health instutes of turkey } \\
\text { (TUSEB) (TURKOCAV) }\end{array}$ & Phase 3 \\
\hline & & & 2 & Day $0+14$ & i.m. & Shifa Pharmed Industrial Co & Phase $2 / 3$ \\
\hline \multirow[t]{3}{*}{ DNA vaccines } & 10 & 10 & 2 & Day $0+21$ & i.m. & $\begin{array}{l}\text { Inovio Pharmaceuticals (INO- } \\
4800+\text { +electroporation) }\end{array}$ & Phase $2 / 3$ \\
\hline & & & 2 & Day $0+14$ & i.m. & $\begin{array}{l}\text { AnGes + TakaraBio + Osaka } \\
\text { University (AG0301-COVID19) }\end{array}$ & Phase $2 / 3$ \\
\hline & & & 3 & $\begin{array}{l}\text { Day } 0+28 \\
+56\end{array}$ & i.d. & Zydus Cadila (nCovvaccine) & Phase 3 \\
\hline
\end{tabular}


Table 1. Main vaccine types and Phase 3-4 candidates as of June 2021 [50] (continued)

\begin{tabular}{|c|c|c|c|c|c|c|c|}
\hline $\begin{array}{l}\text { Vaccine platform } \\
\text { description }\end{array}$ & $\begin{array}{l}\text { Number of } \\
\text { candidate } \\
\text { vaccines }\end{array}$ & $\%$ & $\begin{array}{l}\text { Number } \\
\text { of doses }\end{array}$ & Schedule & $\begin{array}{l}\text { Route of } \\
\text { administration }\end{array}$ & $\begin{array}{l}\text { Developers (Candidate } \\
\text { vaccine type) }\end{array}$ & Phase \\
\hline \multirow{7}{*}{$\begin{array}{l}\text { Protein subunit } \\
\text { vaccines }\end{array}$} & 32 & 31 & 2 & Day $0+21$ & i.m. & Novavax (NVX-CoV2373) & Phase 3 \\
\hline & & & $2-3$ & $\begin{array}{l}\text { Day } 0+28 \\
\text { or Day } 0+ \\
28+56\end{array}$ & i.m. & $\begin{array}{l}\text { Anhui Zhifei Longco (ZF2001- } \\
\text { Recombinant SARS-CoV-2 } \\
\text { Vaccine) }\end{array}$ & Phase 3 \\
\hline & & & 2 & Day $0+21$ & i.m. & $\begin{array}{l}\text { Sanofi Pasteur + GSK } \\
\text { (VAT00002) }\end{array}$ & Phase 3 \\
\hline & & & 2 & Day $0+21$ & i.m. & $\begin{array}{l}\text { Clover Biopharmaceuticals } \\
\text { Inc./GSK/Dynavax (SCB-2019 } \\
+ \text { AS03 or CpG } 1018 \text { adjuvant } \\
\text { plus) }\end{array}$ & Phase $2 / 3$ \\
\hline & & & 2 & Day $0+28$ & i.m. & $\begin{array}{l}\text { Instituto Finlay de Vacunas } \\
\text { (FINLAY-FR-2 anti-SARS- } \\
\text { CoV-2 Vaccine) }\end{array}$ & Phase 3 \\
\hline & & & 2 & Day $0+21$ & i.m. & $\begin{array}{l}\text { Federal Budgetary Research } \\
\text { Institution State Research } \\
\text { Center of Virology and } \\
\text { Biotechnology "Vector" } \\
\text { (EpiVacCorona) }\end{array}$ & Phase 3 \\
\hline & & & 3 & $\begin{array}{l}0+14+28 \\
\text { or Day } 0+ \\
28+56\end{array}$ & i.m. & $\begin{array}{l}\text { Center for Genetic Engineering } \\
\text { and Biotechnology (CIGB-66) }\end{array}$ & Phase 3 \\
\hline $\begin{array}{l}\text { Virus like particle } \\
\text { vaccines }\end{array}$ & 5 & 5 & 2 & Day $0+21$ & i.m. & Medicago Inc. (CoVLP) & Phase $2 / 3$ \\
\hline
\end{tabular}

${ }^{*}$ As of 3 June 2021, WHO has assessed that it meets the necessary criteria for safety and efficacy against COVID-19. \%: clinical pass rate

In the pathogenesis of COVID-19 infection, the SARS-CoV-2 virus enters the cell by binding to the ACE2 receptor of the host cell via the S protein. Then, after the virus leaves the cell, it is phagocytosed by APCs and presented to Th cells. Based on this information, it is aimed to use the S proteins of the virus in COVID-19 vaccine studies to produce antibodies for it. COVID-19 vaccines trials include inactivated virus vaccines, nucleic acid-based vaccines (mRNA and DNA vaccines), vector vaccines, protein-based vaccines, virus-like particle vaccines, and live attenuated virus vaccines [51].

\section{mRNA vaccines}

In mRNA vaccines that provide $S$ protein production, the part of the SARS-CoV-2 genome encoding the S protein is placed in lipid nanoparticles with an RNA molecule to ensure entry into the cell. Upon intramuscular injection of the vaccine, myocytes engulf lipid nanoparticles by endocytosis. After entering the cell, mRNAs released into the cytoplasm enter the cells and cause $\mathrm{S}$ protein production. S proteins secreted out of the cell lead to antibody development by providing both secretory (B cell response) and cellular (cytotoxic $\mathrm{T}$ cell response) immune response with antigenic stimulus. Of the 16 vaccine candidates developed in this way, two of them (Pfizer/BioNTech and Moderna vaccines) have already been approved for use, and 2 [CureVac AG (CVnCoV) and Academy of Military Science (AMS)/(ARCoV)] are in 3rd phase [33, 50, 51].

\section{Pfizer/BioNTech (BNT162b2) vaccine}

It is a vaccine developed in partnership with Germany and USA. In phase 3 randomized controlled trial of the vaccine conducted in five countries, it was reported that in 43,538 volunteers aged 16 and over, 7 days after 2 doses of vaccine administered with 21-day intervals, 8 people in the vaccine group and 162 people in the placebo group developed COVID-19 infection and the effectiveness of the vaccine was $95 \%$. In the same study, vaccine effectiveness was found to be $94.7 \%$ in people aged 65 and over. Mild to moderate local 
adverse effects (84\%) and systemic adverse effects such as allergy, malaise, headache, fever, and Bell's palsy can be observed after vaccination. The Pfizer/BioNTech vaccine has been approved for use in people 16 years of age and older. The disadvantage is that the vaccine can be stored for 6 months at $-70^{\circ} \mathrm{C}$ and 5 days in the refrigerator at $4^{\circ} \mathrm{C}$ [52-54]. In addition, phase 4 studies of the vaccine are ongoing [50].

\section{Moderna vaccine (mRNA 1273)}

Moderna vaccine is an mRNA vaccine produced by a US-based company. It is produced similarly to the Pfizer/BioNTech vaccine, but the structure surrounding the mRNA is different. This vaccine also contains mRNA encoding S protein hidden in lipid nanoparticles. In phase 3 randomized controlled trial of the vaccine, it was reported that COVID-19 infection developed in 11 people in the vaccine group and185 people in the placebo group 14 days after 2 doses of vaccine administered with an interval of 28 days in 30,420 volunteers aged 18 and over, and the effectiveness of the vaccine was $94.1 \%$. In the study, the effectiveness of the vaccine was found to be $86.4 \%$ in people aged 65 and over. After vaccination, a picture of severe COVID-19 can be seen in individuals aged 65 and over, mild to moderate local adverse effects, and systemic adverse effects such as headache, weakness, arthralgia, myalgia, allergy, and anaphylaxis can be seen in the general population. However, these symptoms usually regress spontaneously $[55,56]$. The Moderna vaccine, whose 4th phase studies are ongoing, has been approved for use for those aged 18 and over. The vaccine can be stored for 6 months at $-20^{\circ} \mathrm{C}$ and 30 days in the refrigerator at $4^{\circ} \mathrm{C}[50,57]$.

\section{Vector vaccines}

Vector vaccines are based on the delivery of genes encoding the S protein of SARS-CoV-2 via a vector (usually adenovirus). Of the 18 vaccine candidates developed in this way, 3 were approved for use, and 1 [Cansino (Ad5-nCoV)] received conditional use approval [50,58].

Oxford/Astra Zeneca (ChAdOx1) vaccine

It is a vaccine obtained by transferring the genes encoding $\mathrm{S}$ proteins of SARS-CoV2 to non-replicative chimpanzee adenovirus (ChAdOx1). Phase 1, 2, and 3 studies have been conducted in volunteers over 18 in 3 countries, and phase 4 studies are ongoing [50, 59]. In the phase 1-2-3 study, two doses (28 days apart) of the Oxford/Astra Zeneca vaccine were administered to the vaccine group, and the meningococcal vaccine was administered to the control group. It was stated that COVID-19 infection could develop at least 14 days after the administration of two doses of the vaccine, and the effectiveness of the vaccine was found to be $62.1 \%$. As an adverse effect of the vaccine, transverse myelitis has been reported in 2 patients in the vaccine group and 1 patient in the control group [59].

\section{Cansino (Ad5-nCoV)}

Cansino vaccine has been developed by Beijing Institute in China using adenovirus Type 5 as a vector. 1-2 of the vaccine phases have been made, and 3 and 4 phases are ongoing [50]. In phase 1 and 2 studies, antibodies started to increase 14 days after a dose of vaccine and peaked on the 28th day. Pain (58\%) and systemic adverse effects such as fever, fatigue, headache, and myalgia are the most common local adverse effects. In addition, the vaccine has been given conditional approval for use by the Chinese government [60].

\section{Sputnik V (Gam-COVID-Vac)}

It is a vaccine developed by the Gameleya Institute in Russia. It is a vaccine in which the genes encoding the $\mathrm{S}$ proteins of the SARS-CoV-2 genome are transferred to adenovirus and adenovirus Type 26 and Type 5 viruses and used as vectors $[61,62]$. Phase 1,2 , and 3 studies of the vaccine have been conducted in volunteers [50]. Two doses of vaccine were administered to 22,714 people aged 18 years and older who voluntarily participated in the study at an interval of 21 days. After the first dose of the vaccine, 16 people in the vaccine group and 62 people in the placebo group developed COVID-19 infection, and the effectiveness of the vaccine was $91.6 \%$. While there was no severe COVID-19 infection in the vaccine group, in the placebo group, 20 people had severe COVID-19 infection and based on this finding, the effectiveness of the vaccine in preventing severe COVID-19 infection was determined to be $100 \%$. In addition, mild-to-moderate local 
adverse events that regress spontaneously due to the vaccine have been reported, and no serious adverse events have been reported [61, 62].

\section{Johnson \& Johnson (Ad26.COV2.S)}

It is a vaccine in which adenovirus Type 26 is used as a vector. Phases 1,2, and 3 studies have been completed, and phase 4 study is in progress [50]. In phase 1-2 studies conducted with volunteers aged 18-55 and over 55 years of age, 2 doses of vaccine were administered at an interval of 56 days, and in 402 people, mild to moderate local adverse effects, especially pain at the injection site, and mild to moderate weakness, headache, systemic adverse effects, such as muscle pain, were observed [63]. In a phase 3 study conducted with 43,783 volunteers aged 18 years and older, it was determined that its effectiveness in preventing severe disease 28 days after a single dose vaccination in volunteers was $85.4 \%[64,65]$. The vaccine has been approved for use for those aged 18 and over and is administered as a single dose [65].

\section{Inactivated virus vaccines}

The basis of inactivated virus vaccines is based on the inactivation of SARS-CoV-2 viruses with betapropionylactone. Of the 16 vaccine candidates developed this way, 3 have been approved for use $[50,58]$.

\section{CoronaVac (Sinovac)}

Sinovac vaccine is an inactivated virus vaccine produced by the Chinese government. In phase 1 and phase 2 studies of the vaccine, whose phase 4 studies are ongoing, vaccine doses of $3 \mu \mathrm{g}$ ( 2 doses in 2 groups with an interval of 14 days and 28 days) or $6 \mu \mathrm{g}$ vaccine doses ( 2 groups for 14 days and 28 days) was administered in a placebo-controlled manner in volunteers aged 18-59 years. Following 2 doses of Sinovac at a dose of $3 \mu \mathrm{g} 14$ days apart, at a rate of $92.4 \%$ and $94.1 \%$ neutralizing antibodies developed in the participants after 14 and 28 days, respectively. In the dose of $6 \mu \mathrm{g}$, which was administered 2 doses at an interval of 14 days, neutralizing antibodies developed at the rate of $98.3 \%$ after 14 days and $99.2 \%$ after 28 days. In 2 doses of $3 \mu \mathrm{g}$ Sinovac vaccine administered 28 days apart, the rate of neutralizing antibodies was $97.4 \%$ after 14 days and $99.2 \%$ after 28 days; at a dose of $6 \mu \mathrm{g}$ ( 2 doses), it is $100 \%$ after 14 days and $100 \%$ after 28 days, and the immunogenicity of the vaccine is good [66]. Mild-to-moderate adverse events (most of which regressed within $48 \mathrm{~h}$ ) were reported in $21 \%$ of volunteers aged 60 years and older, mainly injection site pain (9\%), fever, and headache [67]. In one of the phase 3 studies, the effectiveness of the vaccine was found to be $83.5 \%$. Sinovac vaccine can be administered to individuals aged 18 years and older. Storage conditions of the vaccine are $2-8^{\circ} \mathrm{C}[68]$.

\section{Sinopharm/WIBP-CorV}

Phase $1 / 2$ studies of the vaccine, developed and approved for use by the Chinese National Pharmaceutical Group, were completed. Phase 3 and 4 studies continue. In the phase 1/2 study, antibodies started to rise 14 days after the dose of vaccine and peaked on the 42 nd day. $29 \%$ of vaccinated individuals have at least 1 adverse reaction 7 days after vaccination, and the most common systemic adverse effect is mild to moderate fever [69]. The efficacy of the Sinopharm/WIBP vaccine was found to be 79\% [70].

\section{Bharat Biotech (BBV152)}

BBV152 (produced by Bharat Biotech) is a whole virion $\beta$-propiolactone inactivated SARS-CoV-2 vaccine. The SARS-CoV-2 strain (NIV-2020-770) used in the development of the BBV152 vaccine was obtained from tourists visiting New Delhi, India. Phase 3 studies of the vaccine, of which phase 1/2 studies have been performed, are ongoing [50,71]. Within 7 days after vaccination, patients developed pain and swelling at the injection site (local adverse effect), and systemic adverse reactions such as fever, fatigue or malaise, myalgia, body aches, headache, nausea or vomiting, anorexia, chills, general rash, and diarrhea have been reported. The vaccine can be stored at $2-8^{\circ} \mathrm{C}[71]$.

\section{DNA vaccines}

DNA vaccines are based on the insertion of S-protein-encoding genes of SARS-CoV-2 into plasmid DNA. After the DNA enters the host cell, mRNA is formed, and S proteins are produced and released. Then, the 
$S$ proteins are recognized by the antigen-presenting cells, and antibody production takes place. Of the 10 vaccine candidates under development, 3 [Inovio Pharmaceuticals (INO-4800), Osaka University (AG0301-COVID), Zydus Cadila (nCov vaccine)] are in phase 3, and only 3 phase study reports of INO-4800 have been reported [50,58].

\section{Inovio Pharmaceuticals (INO-4800+electroporation)}

The INO-4800 vaccine, administered intradermally (ID), is the first DNA vaccine for which reports of a phase 3 trial have been submitted as of June 2021. In the phase 3 study, 2 doses of $1 \mathrm{mg}$ or $2 \mathrm{mg}$ INO-4800 vaccine were administered 28 days apart to 401 volunteers. In this randomized controlled study, which has also a placebo group, it was determined that the dose administered to the individuals was not effective in the development of adverse effects. In addition, antibody levels were found to be significantly higher in the $2 \mathrm{mg}$ dose group compared to the $1 \mathrm{mg}$ dose group. For this reason, it was decided to use the $2 \mathrm{mg}$ vaccine in the ongoing phase efficacy evaluations of the vaccine. It has been reported that the vaccine can be used in adults of all ages [72].

\section{Protein subunit vaccines}

Protein subunit vaccines are vaccines in which the immune system is stimulated by administering SARS-CoV-2 proteins to the host. Phase 3 study of 5 [Novavax, Anhui Zhifei Longcom, Sanofi Pasteur+GSK (VAT00002), Clover Biopharmaceuticals Inc./GSK/Dynavax, FINLAY-FR-2 anti-SARS-CoV-2 Vaccine, EpiVac Corona] out of 32 vaccine candidates in this group is ongoing, and 2 of them [Novavax vaccine and Anhui Zhifei Longcom (Recombinant SARS-CoV-2 vaccine)] have reported phase 3 reports [50].

\section{Novavax (NVX-CoV2373)}

15,000 volunteers aged 18-84 years participated in the placebo-controlled phase 3 study of the Novavax vaccine. It has been determined that COVID-19 infection may develop 7 days after the administration of two doses of vaccine with an interval of 21 days. The efficacy of the vaccine was reported as $95.6 \%$ in the original (non-variant) strains, $85.6 \%$ in the UK variant, $60 \%$ in the South African variant, and $89.3 \%$ in all groups. Local and systemic adverse effects of the vaccine are seen at mild to moderate levels. The storage conditions of the vaccine are between $2-8^{\circ} \mathrm{C}[73,74]$.

\section{Anhui Zhifei Longcom (ZF2001-Recombinant SARS-CoV-2 vaccine)}

The ZF2001 vaccine is based on the use of a dimeric form of the RBD of the SARS-CoV-2 spike protein as antigen. Phase 1 and phase 2 results of the vaccine have been reported, and phase 3 studies are ongoing. Participants aged 18-59 were divided into three groups ( $25 \mu \mathrm{g}$ dose vaccine group, $50 \mu \mathrm{g}$ dose vaccine group, and placebo group), and two doses of vaccine were administered 30 days apart. The adverse events that developed in the groups were compared, and in $50 \mu \mathrm{g}$ dose of vaccine administered group, more local [mostly pain at the injection site (55\%) and itching (35\%)] and systemic [cough (15\%), nausea (10\%), headache (5\%) and fatigue (5\%)] adverse effects were observed than $50 \mu \mathrm{g}$ dose of vaccine administered group. Therefore, it was concluded that a $25 \mu \mathrm{g}$ dose of vaccine should be used in phase 3 studies [75].

\section{Virus-like particle vaccines}

Virus-like particle vaccines are vaccines that use virus-like particles that do not contain the genetic material of SARS-CoV-2 but contain its proteins. These vaccines, which are difficult to produce, cause a strong immune response [58]. Phase studies of 2 vaccine candidates of the 5 in the virus-like particle vaccine group (RBD SARS-CoV-2 HBsAg VLP Vaccine, CoVLP) are ongoing, and 1 of them (CoVLP) is in phase 2/3 [50].

\section{Medicago Inc. (CoVLP)}

It is a virus-like particle vaccine candidate in phase 3 and produced from plants carrying the SARS-CoV-2 S glycoprotein (CoVLP) adjuvanted with AS03. The reported phase 2 study of the vaccine was conducted in volunteers aged 18-64 (adults) and 65 years and older (older adults). After a single dose of AS03-adjuvant CoVLP, it caused a significant interferon- $\gamma$ (IFN- $\gamma$ ) response in both groups, but adults developed a greater humoral response than older adults, and a stronger IFN- $\gamma$ and interleukin-4 (IL-4) cellular response has 
been reported in older adults after two doses of AS03-adjuvant CoVLP. Safety reports of the vaccine will be reported at the end of the phase 3 study [76].

\section{Live attenuated virus vaccines}

These are the types of vaccines in which viruses obtained by reducing the disease ability of SARS-CoV-2 in special (in vitro) environments are used. Although there are two candidates for vaccines working on this principle [Codagenix (COVI-VAC) and Meissa vaccines (MV-014-212)], both are still in phase 1 [50, 58].

\section{Conclusion}

Vaccine studies on COVID-19, which causes deaths due to ARDS, continue all over the world. As a result of the antigen presentation of the vaccine, a specific humoral and cellular immune response against the virus is stimulated and IgM and IgG type antibodies are formed against SARS-CoV-2. There are 287 COVID-19 vaccine studies worldwide, 102 of which are in clinical phase studies, and 185 are in the process of preclinical studies. Currently, Pfizer/BioNTech, Moderna, Oxford/Astra Zeneca, Johnson \& Johnson, Sinopharm/WIBP-CorV, and CoronaVac vaccines are used all over the world, which have been reported to meet the safety and efficacy criteria against COVID-19 by WHO. Phase 4 studies of Moderna (mRNA 1273), Pfizer/BioNTech (BNT162b2), Oxford/Astra Zeneca (ChAdOx1), CansinoBiological Inc. (Ad5-nCoV), and CoronaVac (Sinovac) vaccines, and phase 3 studies of 25 vaccines are still in progress.

\section{Abbreviations}

ACE: angiotensin converting enzyme

ADE: antibody-dependent enhancement

ARDS: acute respiratory failure syndrome

COVID-19: coronavirus disease 2019

E: envelope

HE: hemagglutinin esterase

IgM: immunoglobulin M

M: membrane

MHC: major histocompatibility complex

$\mathrm{N}$ : nucleocapsid

ORFs: open reading frames

RBD: receptor binding domain

S: spike

SARS-CoV-2: severe acute respiratory syndrome coronavirus 2

WHO: World Health Organization

\section{Declarations}

\section{Author contributions}

SH and HD wrote the manuscript; SH and HD conceived, wrote, and revised the manuscript.

\section{Conflicts of interest}

The authors declare that they have no conflicts of interest.

\section{Ethical approval}

Not applicable. 


\section{Consent to participate}

Not applicable.

Consent to publication

Not applicable.

Availability of data and materials

Not applicable.

Funding

Not applicable.

\section{Copyright}

(C) The Author(s) 2021.

\section{References}

1. Li G, Fan Y, Lai Y, Han T, Li Z, Zhou P, et al. Coronavirus infections and immune responses. J Med Virol. 2020;92:424-32.

2. Salute MD. Nuovo coronavirus [Internet]. Roma: I: Governo-Repubblica Italiana; 2020. c2021 [cited 2021 May 5]. Available from: http://www.salute.gov.it/nuovocoronavirus

3. Del Rio C, Malani PN. 2019 novel coronavirus-important information for clinicians. JAMA. 2020;323:1039-40.

4. Salute MD. Covid-19-Situazione in Italia [Internet]. Roma: I: Governo-Repubblica Italiana; 2020. c2021 [cited 2021 May 5]. Available from: http://www.salute.gov.it/portale/ nuovocoronavirus /dettaglioContenutiNuovoCoronavirus.jsp?lingua=italiano\&id=5351\&area= nuovoCoronavirus\&menu=vuoto

5. Guo YR, Cao QD, Hong ZS, Tan YY, Chen SD, Jin HJ, et al. The origin, transmission and clinical therapies on coronavirus disease 2019 (COVID-19) outbreak-an update on the status. Mil Med Res. 2020;7:11.

6. Chen Y, Liu Q, Guo D. Emerging coronaviruses: genome structure, replication, and pathogenesis. J Med Virol. 2020;92:418-23.

7. World Health Organization [Internet]. WHO coronavirus (COVID-19) dashboard, 2021. [cited 2021 May 5]. Available from: https://covid19.who.int/

8. Mavi D, İnkaya AÇ. COVID-19: immün patogenez. FLORA. 2020;25. Turkce.

9. Masihi KN. Fighting infection using immunomodulatory agents. Expert Opin Biol Ther. 2001;1:641-53.

10. Ou X, Liu Y, Lei X. Characterization of spike glycoprotein of SARS-CoV-2 on virus entry and its immune cross-reactivity with SARS-CoV. Nat Commun. 2020;11:1620.

11. Kahraman EP, Altındis M. COVID-19 asıları; pandemide sona dogru? J Biotechnol and Strategic Health Res. 2020;4:240-9. Turkce.

12. Ge H, Wang X, Yuan X, Xiao G, Wang C, Deng T, et al. The epidemiology and clinical information about COVID-19. Eur J Clin Microbiol Infect Dis. 2020;14:1011-9.

13. Yi Y, Lagniton PN, Ye S, Li E, Xu RH. COVID-19: what has been learned and to be learned about the novel coronavirus disease. Int J Biol Sci. 2020;16:1753-66.

14. Udugama B, Kadhiresan P, Kozlowski HN, Malekjahani A, Osborne M, Li VY, et al. Diagnosing COVID-19: the disease and tools for detection. ACS Nano. 2020;14:3822-35.

15. Kannan S, Ali PSS, Sheeza A, Hemalatha K. COVID-19 (novel coronavirus 2019)—recent trends. Eur Rev Med Pharmacol Sci. 2020;24:2006-11. 
16. Baloch S, Baloch MA, Zheng T, Pei X. The coronavirus disease 2019 (COVID-19) pandemic. Tohoku J Exp Med. 2020;250:271-8.

17. Jiang F, Deng L, Zhang L, Cai Y, Cheung CW, Xia Z, et al. Review of the clinical characteristics of coronavirus disease 2019 (COVID-19). J Gen Intern Med. 2020;35:1545-9.

18. Harapan H, Itoh N, Yufika A, Winardi W, Keam S, Te H, et al. Coronavirus disease 2019 (COVID-19): a literature review. J Infect Public Health. 2020;13:667-73.

19. Jin Y, Yang H, Ji W, Wu W, Chen S, Zhang W, et al. Virology, epidemiology, pathogenesis, and control of COVID-19. Viruses. 2020;12:372.

20. Hindistan S, Kazak A. Vaccination studies against COVID-19 agent: current status. Bezmialem Science. 2020;8:145-52.

21. Weiss SR, Leibowitz JL. Coronavirus pathogenesis. Adv Virus Res. 2011;81:85-164.

22. Lissenberg A, Vrolijk MM, van Vliet AL, Langereis MA, de Groot-Mijnes JD, Rottier PJ, et al. Luxury at a cost? Recombinant mouse hepatitis viruses expressing the accessory hem agglutinin esterase protein display reduced fitness in vitro. J Virol. 2005;79:15054-63.

23. Graham RL, Baric RS. Recombination, reservoirs, and the modular spike: mechanisms of coronavirus cross-species transmission. J Virol. 2010;84:3134-46.

24. De Haan CA, de Wit M, Kuo L, Montalto-Morrison C, Haagmans BL, Weiss SR, et al. The glycosylation status of the murine hepatitis coronavirus M protein affects the interferogenic capacity of the virus in vitro and its ability to replicate in the liver but not the brain. Virology. 2003;312:395-406.

25. Ruch TR, Machamer CE. The coronavirus E protein: assembly and beyond. Viruses. 2012;4:363-82.

26. Escors D, Ortego J, Enjuanes L. The membrane M protein of the transmissible gastroenteritis coronavirus binds to the internal core through the carboxy-terminus. Adv Exp Med Biol. 2001;494:589-93.

27. Khailany AR, Safdar M, Özaslan M. Genomic characterization of a novel SARS-CoV-2. Gene Rep. 2020;19:100682.

28. Belouzard S, Chu VC, Whittaker GR. Activation of the SARS coronavirus spike protein via sequential proteolytic cleavage at two distinct sites. Proc Natl Acad Sci U S A. 2009;106:5871-6.

29. Varga Z, Flammer AJ, Steiger P, Haberecker M, Andermatt R, Zinkernagel AS, et al. Endothelial cell infection and endotheliitis in COVID-19. Lancet. 2020;395:1417-8.

30. Magro C, Mulvey JJ, Berlin D, Nuovo G, Salvatore S, Harp J, et al. Complement associated microvascular injury and thrombosis in the pathogenesis of severe COVID-19 infection: a report of five cases. Transl Res. 2020;220:1-13.

31. Zhang Y, Geng X, Tan Y, Li Q, Xu C, Xu J, et al. New understanding of the damage of SARS-CoV-2 infection outside the respiratory system. Biomed Pharmacother. 2020;127:110195.

32. Yip MS, Leung HL, Li PH, Cheung CY, Dutry I, Li D, et al. Antibody-dependent enhancement of SARS coronavirus infection and its role in the pathogenesis of SARS. Hong Kong Med J.2016;22 Suppl 4:25-31.

33. Wang SF, Tseng SP, Yen CH, Yang JY, Tsao CH, Shen CW, et al. Antibody-dependent SARS coronavirus infection is mediated by antibodies against spike proteins. Biochem Biophys Res Commun. 2014;451:208-14.

34. Liu J, Wu P, Gao F, Qi J, Kawana-Tachikawa A, Xie J, et al. Novel immunodominant peptide presentation strategy: a featured HLAA*2402-restricted cytotoxic T-lymphocyte epitope stabilized by intrachain hydrogen bonds from severe acute respiratory syndrome coronavirus nucleocapsid protein. J Virol. 2010;84:11849-57.

35. Zhao J, Yuan Q, Wang H, Liu W, Liao X, Su Y, et al. Antibody responses to SARS-CoV-2 in patients of novel coronavirus disease 2019. Clin Infect Dis. 2020;71:2027-34. 
36. Menachery VD, Schäfer A, Burnum-Johnson KE, Mitchell HD, Eisfeld AJ, Walters KB, et al. MERS-CoV and H5N1 influenza virus antagonize antigen presentation by altering the epigenetic landscape. Proc Natl Acad Sci U S A. 2018;115:E1012-21.

37. Okba NMA, Müller MA, Li W, Wang C, GeurtsvanKessel CH, Corman VC, et al. Severe acute respiratory syndrome coronavirus 2-specific antibody responses in coronavirus disease patients. Emerg Infect Dis. 2020;26:1478-88.

38. Ni L, Ye F, Cheng ML, Feng Y, Deng YQ, Zhao H, et al. Detection of SARS-CoV-2-specific humoral and cellular immunity in COVID-19 convalescent individuals. Immunity. 2020;52:971-7.e3.

39. Ibarrondo FJ, Fulcher JA, Goodman-Meza D, Elliot J, Hofman C, Hausner MA, et al. Rapid decay of anti-SARS-CoV-2 antibodies in persons with mild COVID-19. N Engl J Med. 2020;383:1085-7.

40. Long QX, Tang XJ, Shi QL, Li Q, Deng HJ, Yuan J, et al. Clinical and immunological assessment of asymptomatic SARS-CoV-2 infections. Nat Med. 2020;26:1200-4.

41. Gudbjartsson DF, Norddahl GL, Melsted P, Gunnarsdottir K, Holm H, Eythorsson E, et al. Humoral immune response to SARS-CoV-2 in Iceland. N Engl J Med. 2020;383:1724-34.

42. Lee JS, Kim SY, Kin TS, Hong KH, Ryoo NH, Lee J, et al. Evidence of severe acute respiratory syndrome coronavirus 2 reinfection after recovery from mild coronavirus disease 2019. Clin Infect Dis. 2020;73:e3002-8.

43. Carillo J, Izquierdo-Useros N, Avila-Nieto C, Pradenas E, Clotet B, Blanco J. Humoral immune responses and neutralizing antibodies against SARS-CoV-2; implications in pathogenesis and protective immunity. Biochem Biophys Res Commun. 2021;538:187-91.

44. Grifoni A, Weiskopf D, Ramirez SI, Mateus J, Dan JM, Moderbacher CR, et al. Targets of T cell responses to SARS-CoV-2 coronavirus in humans with COVID-19 disease and unexposed individuals. Cell. 2020;181:1489-501.e15.

45. Le Bert N, Tan AT, Kunasegaran K, Tham CYL, Hafezi M, Chia A, et al. SARS-CoV-2-specific T cell immunity in cases of COVID-19 and SARS, and uninfected controls. Nature. 2020;584:457-62.

46. Braun J, Loyal L, Frentsch M, Wendisch D, Georg P, Kurth F, et al. SARS-CoV-2 reactive T cells in healthy donors and patients with COVID-19. Nature. 2020;587:270-4.

47. Sekine T, Perez-Potti A, Rivera-Ballesteros O, Strålin K, Gorin JB, Olsson A, et al. Robust T cell immunity in convalescent individuals with asymptomatic or mild COVID-19. Cell. 2020;183:158-68.e14.

48. Gallais F, Velay A, Nazon C, Wendling MJ, Partisani M, Sibilia J, et al. Intrafamilial exposure to SARS-CoV-2 associated with cellular immune response without seroconversion, France. Emerg Infect Dis. 2021;27:113-21.

49. Azalp A. COVID-19 vaccines: light at the end of the tunnel. Archives Medical Review Journal. 2020; 9:94-100.

50. World Health Organization [Internet]. COVID-19 vaccine tracker and landscape. [cited 2021 May 16]. Available from: https://www.who.int/publications/m/item/draft-landscape-of-covid19-candidate-vaccines

51. Poland GA, Ovsyannikova IG, Kennedy RB. SARS-CoV-2 immunity: review and applications to phase 3 vaccine candidates. Lancet. 2020;396:1595-606.

52. Polack FP, Thomas SJ, Kitchin N, Ablason J, Gurtman A, Lockhart S, et al. Safety and efficacy of the BNT162b2 mRNA Covid-19 vaccine. N Engl J Med. 2020;383:2603-15.

53. World Health Organization [Internet]. Background document on the mRNA vaccine BNT162b2 (Pfizer/ BioNTech) against Covid-19. c2021 [cited 2021 May 17]. Available from: https://www.who.int/ publications/i/item/background-document-on-mrna-vaccine-bnt162b2-(pfizer-biontech)-againstcovid-19

54. Shimabukoro T, Nair N. Allergic reactions including anaphylaxis after receipt of the first dose of Pfizer-BioNTech COVID-19 vaccine. JAMA. 2021;325:780-1. 
55. Baden LR, El Sahyl HM, Essink B, Kotloff K, Frey S, Novak R, et al. Efficacy and safety of the mRNA-1273 SARS-CoV-2 vaccine. N Engl J Med. 2021;384:403-16.

56. Centers for Disease Kontrol and Prevention [Internet]. Allergic reactions including anaphylaxis after receipt of the first dose of Moderna Covid-19 vaccine-United States, December 21, 2020-January 20, 2021. [cited 2021 Jun 25]. Available from: https://www.cdc.gov/mmwr/volumes/70/wr/mm7004e1. htm?s_cid=mm7004e1_w

57. World Health Organization [Internet]. Interim recommendations for use of the Moderna mRNA1273 vaccine against Covid-19. c2021 [cited 2021 Jun 25]. Available from: https://www.who.int/ publications/i/item/interim-recommendations-for-use-of-the-moderna-mrna-1273-vaccine-againstcovid-19

58. Callaway E. The race for coronavirus vaccines: a graphical guide. Nature. 2020;580:576-7.

59. Voysey M, Costa Clemens SA, Madhi SA, Weckx LY, Folegatti PM, Aley PK, et al. Safety and efficacy of the ChAdOx1 nCoV-19 vaccine (AZD1222) against SARS-CoV-2: an interim analysis of four randomised controlled trials in Brazil, South Africa and the UK. Lancet. 2021;397:99-111.

60. Zhu FC, Li YH, Guan XH, Hou LH, Wang WJ, Li JX, et al. Safety, tolerability, and immunogenicity of a recombinant adenovirus type-5 vectored COVID-19 vaccine: a dose-escalation, open-label, non-randomised, first-in-human trial. Lancet. 2020;395:1845-54.

61. Logunov DY, Dolzhikova IV, Zubkova OV, Tukhvatulin AI, Shcheblyakov DV, Dzharullaeva AS, et al. Safety and immunogenicity of an rAd26 and rAd5 vector based heterologous prime-boost Covid-19 vaccine in two formulations: two open, non-randomised phase 1/2studies from Russia. Lancet. 2020;396:887-97.

62. Logunov DY, Dolzhikova IV, Shcheblyakov D, Tukhvatulin AI, Zubkova OV, Dzharullaeva AS, et al. Safety and immunogenicity of an rAd26 and rAd5 vector based heterologous prime-boost Covid-19 vaccine: an interim analysis of a randomised controlled phase 3 trial in Russia. Lancet. 2021;397:671-81.

63. Sadoff J, Le Gars M, Shukarev G, Heerwegh D, Truyers C, de Groot AM, et al. Interim results of a phase 1-2a trial of Ad26.COV2.S Covid-19 vaccine. N Engl J Med. 2021;384:1824-35.

64. jnj.com [Internet]. Johnson \& Johnson COVID-19 vaccine authorized by U.S. FDA for emergency use-first single-shot vaccine in fight against global pandemic. c1997-2021 [cited 2021 Jun 26]. Available from: https://www.jnj.com/johnson-johnson-covid-19-vaccine-authorized-by-u-s-fda-for-emergencyusefirst-single-shot-vaccine-in-fight-against-global-pandemic

65. World Health Organization [Internet]. The Janssen Ad26.COV2.S COVID-19 vaccine: what you need to know. c2021 [cited 2021 Jun 16]. Available from: https://www.who.int/news-room/feature-stories/ detail/the-j-j-covid-19-vaccine-what-you-need-to-know

66. Zhang Y, Zeng G, Pan H, Li C, Hu Y, Chu K, et al. Safety, tolerability, and immunogenicity of an inactivated SARS-CoV-2 vaccine in healty adults aged 18-59 years: a randomised, double-blind, placebo-controlled, phase 1/2 clinical trial. Lancet Infect Dis. 2021;21:181-92.

67. Wu Z, Hu Y, Xu M, Chen Z, Yang W, Jiang Z, et al. Safety, tolerability, and immunogenicity of an inactivated SARS-CoV-2 vaccine (CoronaVac) in healty adults aged 60 years and older: a randomised, double-blind, plasebo-controlled, phase 1/2 clinical trial. Lancet Infect Dis. 2021;21:803-12.

68. T.C Sağlık Bakanlığı [Internet]. COVID-19 aşısı bilgilendirme platformu. c2021 [cited 2021 May 13]. Available from: https://covid19asi.saglik.gov.tr/TR-77693/covid-19-asisi.html

69. Xia S, Zhang Y, Wang Y, Wang H, Yang Y, Gao GF, et al. Safety and immunogenicity of an inactivated SARSCoV-2 vaccine, BBIBP-CorV: a randomised, double-blind, placebo-controlled, phase $1 / 2$ trial. Lancet Infect Dis. 2020;21:39-51.

70. World Health Organization [Internet]. The Sinopharm COVID-19 vaccine: what you need to know. [cited 2021 May 5]. Available from: https://www.who.int/news-room/feature-stories/detail/the-sinopharmcovid-19-vaccine-what-you-need-to-know 
71. Ella R, Reddy S, Jogdand H, Sarangi V, Ganneru B, Prasad S, et al. Safety and immunogenicity of an inactivated SARS-CoV-2 vaccine, BBV152: interim results from a double-blind, randomised, multicentre, phase 2 trial, and 3-month follow-up of a double-blind, randomised phase 1 trial. Lancet Infect Dis. 2021;21:950-61.

72. Mammen P Jr., Tebas P, Agnes J, Giffear M, Kraynyak KA, Blackwood E, et al. Safety and immunogenicity of INO-4800 DNA vaccine against SARS-CoV-2: a preliminary report of a randomized, blinded, placebo-controlled, Phase 2 clinical trial in adults at high risk of viral exposure. medRxiv 21256652 [Preprint]. c2021 [cited 2021 May 20]. Available from: https://doi.org/10.1101/2021.05.07.21256652

73. Mahase E. Covid-19: Novavax vaccine efficacy is $86 \%$ against UK variant and $60 \%$ against South African variant. BMJ. 2021;372:n296.

74. ir.novavax.com [Internet]. Novavax: Novavax COVID-19 vaccine demonstrates $89.3 \%$ efficacy in UK phase 3 trial. [cited 2021 Jun 25]. Available from: https://irnovavax.com/news-releases/news-releasedetails/novavax-covid-19-vaccine-demonstrates-893-efficacy-uk-phase-3

75. Yang S, Li Y, Dai L, Wang J, He P, Li C, et al. Safety and immunogenicity of a recombinant tandem-repeat dimeric RBD-based protein subunit vaccine (ZF2001) against COVID-19 in adults: two randomised, double-blind, placebo-controlled, phase 1 and 2 trials. Lancet Infect Dis. 2021;21:1107-19.

76. Gobeil P, Pillet S, Séguin A, Boulay I, Mahmood A, Vinh DC, et al. Phase 2 randomized trial of an AS03 adjuvanted plant-based virus-like particle vaccine for Covid-19 in healthy adults, older adults and adults with comorbidities. medRxiv 21257248 [Preprint]. c2021 [cited 2021 May 25]. Available from: https://doi.org/10.1101/2021.05.14.21257248 